\title{
Process Optimization of L-Glutaminase Production; a Tumour Inhibitor from Marine Endophytic Isolate Aspergillus sp. ALAA-2000 \\ Mervat Morsy Abbas Ahmed ${ }^{1,2 *}$, Taher M Taha ${ }^{3,4}$, Nageh F Abo-Dahab ${ }^{3}$ and Fareed SM Hassan ${ }^{3}$ \\ ${ }^{1}$ Department of Biological Sciences, Faculty of Sciences, King Abdulaziz University (KAU), Saudi Arabia \\ ${ }^{2}$ Chemistry of Natural and Microbial Products Department, National Research Centre, Dokki, Giza, Egypt \\ ${ }^{3}$ Botany and Microbiology Department, Faculty of Science, Al-Azhar University, Assuit, Egypt \\ ${ }^{4}$ Biology Department, Faculty of Science and Arts, Al Baha University, Saudi Arabia
}

\begin{abstract}
L-Glutaminases have received significant attention recently owing to their potential applications. All endophytic fungi recovered from the marine soft sponge Aplysina fistularis were able to produce L-glutaminase. During screening program, Aspergillus sp. ALAA-2000 showed the highest L-glutaminase production levels. The production of L-glutaminase by Aspergillus sp. ALAA-2000 was evaluated under different fermentation modes and parameters. The L-glutaminase synthesis was increased their yield after the optimization of fermentation parameters. The hot water $40^{\circ} \mathrm{C}$ was the best leaching agent extracted of soy bean for L-glutaminase production $(21.89 \mathrm{U} / \mathrm{ml})$ under solid state fermentation (SSF). The highest L-glutaminase activity $(91.92 \mathrm{U} / \mathrm{ml})$ was achieved after two days incubation period under submerged fermentation (SmF). L-glutamine, dextrose, cysteine and Magnesium chloride supported the highest L-glutaminase production by Aspergillus sp. ALAA-2000 under SmF at pH 4 and $27^{\circ} \mathrm{C}$. Single peak of L-glutaminase was obtained from the culture supernatant of Aspergillus sp. ALAA-2000 through ammonium sulfate precipitation and DEAE-cellulose column chromatographyrefer to the mono meric nature of L-glutaminase enzyme. The parameters of purified L-glutaminase were optimized as follow: $\mathrm{pH} 10$, stable at $40^{\circ} \mathrm{C}$ to $50^{\circ} \mathrm{C}$, reaction time $30 \mathrm{~min}$ and substrate concentration $4.38 \mathrm{mg} / \mathrm{ml}$. Whereas the maximum activator cation is $\mathrm{Na}^{+}$and different EDTA concentrations have no effect on L-glutaminase activity which means that L-glutaminase enzymes was represent as a non-metallic enzyme.
\end{abstract}

Keywords: L-glutaminase; Marine endophytic Aspergillus sp.; Fermentation; Optimization; Purification

\section{Introduction}

L-Glutaminase (L-glutamine amidohydrolase E.C 3.5.1.2) catalyses the hydrolysis of L-glutamine to glutamic acid and ammonia. In recent years, glutaminase has gained much attention due to their potential applications in pharmaceuticals as an anti-leukemic agent [1,2], flavor enhancing agent [3] and an efficient anti-retroviral agent [4]. Another most promising application of glutaminase is in biosensors for monitoring glutamine levels in mammalian and hybridoma cell cultures without the need of separate measurement of glutamic acid [5]. L-Glutaminase is widely distributed in animal tissues, plants and in a variety of microorganisms including bacteria, fungi and yeast [6-8] of which the most potent producers are fungi [9]. On an industrial scale, glutaminases are produced mainly by Aspergillus and Trichoderma [10-13]. The marine endophytic microflora in the coming decades will be the nature's best source of chemicals. Natural products metabolized from endophytic microorganisms represent desirable sources for effective therapeutic enzymes $[8,14,15]$. Marine fungi are rich profile of biologically active metabolites, especially from genera Penicillium, Aspergillus and Fusarium have been used aiming the development of novel therapies for treating cancer. Whereas the marine fungi are least studied than terrestrial counterparts and other ecological group, they have to study due to their production of new metabolites which are not found in terrestrial fungi [16].

Different methods of fermentation technology can be applied for the production of L-glutaminase. Commercial production of L-glutaminase had been carried out using submerged fermentation $(\mathrm{SmF})$ technique $[17,18]$. But nowadays, solid state fermentation (SSF) has been emerged as a promising technology for the development of several bioprocesses and products including the production of therapeutic enzymes on a large-scale [19]. The primary advantage of SSF is the fact that many metabolites are produced at higher concentration.
Thus the present study, focuses on the L-glutaminase production as potent anticancer agents from a potential of culturable marine endophytic isolate Aspergillus sp. ALAA-2000 isolated from the internal healthy tissue of marine invertebrates as well as develop an economically viable bioprocess for production of L-glutaminase by evaluating and optimizing process parameters through manipulating the nutritional and physical parameters using low cost substrates.

\section{Materials and Methods}

\section{Microorganism and culture maintenance conditions}

Eighteen fungal isolates used in this study were isolated from Egyptian marine sponge Aplysina fistularis, a rich source of endophytic microorganisms on the isolation media peptone yeast extract glucose agar, potato dextrose agar and malt agar [20]. The fungal cultures were purified, maintained at $4^{\circ} \mathrm{C}$ until use and examined for the production of L-glutaminase enzyme.

\section{Screening of fungal isolates for L-glutaminase productivity}

Screening of fungal isolates for L-glutaminase activity was performed using the modified Czapek Dox medium (glucose $2 \mathrm{~g}$,

*Corresponding author: Mervat Morsy Abbas Ahmed, Department of Biological Sciences, Faculty of Sciences, King Abdulaziz University (KAU), Saudi Arabia, Tel: 0000-0002-0680-3205; E-mail: m_morsy_70@yahoo.com

Received July 03, 2016; Accepted July 29, 2016; Published August 09, 2016

Citation: Ahmed MMA, Taha TM, Abo-Dahab NF, Hassan FSM (2016) Process Optimization of L-Glutaminase Production; a Tumour Inhibitor from Marine Endophytic Isolate Aspergillus sp. ALAA-2000. J Microb Biochem Technol 8: 382 389. doi: 10.4172/1948-5948.1000313

Copyright: (c) 2016 Abd-El-Karem Y, et al. This is an open-access article distributed under the terms of the Creative Commons Attribution License, which permits unrestricted use, distribution, and reproduction in any medium, provided the original author and source are credited. 
L-glutamine $10 \mathrm{~g}, \mathrm{KH}_{2} \mathrm{PO}_{4} 1.52 \mathrm{~g}, \mathrm{KCl} 0.52 \mathrm{~g}, \mathrm{MgSO}_{4} .7 \mathrm{H}_{2} \mathrm{O} 0.52 \mathrm{~g}$, $\mathrm{FeSO}_{4} .7 \mathrm{H}_{2} \mathrm{O} 0.01 \mathrm{~g}$, agar $20 \mathrm{~g}$, and distilled water $1000 \mathrm{~mL}$ ) for the plate assay, $3 \mathrm{~mL}$ of $2.5 \%$ stock solution of phenol red in ethanol ( $\mathrm{pH} 6.2$ ) was added to $1000 \mathrm{~mL}$ of Czapek Dox medium. After $72 \mathrm{~h}$ of incubation at $26 \pm 1^{\circ} \mathrm{C}$, the appearance of a pink zone around the fungal colony in an otherwise yellow medium indicated L-glutaminase activity. The fungus which shows highest productivity was subsequently identified and selected to study the optimal conditions for L-glutaminase production in submerged and solid state fermentation.

\section{L-Glutaminase assay}

The activity of L-glutaminase is determined by estimating the amount of $\mathrm{NH}_{3}$ liberated from glutamine. $0.5 \mathrm{ml}$ of enzyme preparation was added to $0.5 \mathrm{ml}$ of $0.04 \mathrm{M} \mathrm{L}$-glutamine $0.5 \mathrm{ml}$ distilled water and $0.5 \mathrm{ml}$ of $0.1 \mathrm{M}$ phosphate buffer $(\mathrm{pH} 8)$ then incubated at $37^{\circ} \mathrm{C}$ for 30 min. After incubation, $0.5 \mathrm{ml}$ of $1.5 \mathrm{M}$ trichloroacetic acid was added to stop the enzymatic reaction. Blank was run by adding the enzyme preparation after the addition of trichloroacetic acid. $0.1 \mathrm{ml}$ of above mixture was taken and added to $3.7 \mathrm{ml}$ of distilled water followed by addition of $0.2 \mathrm{ml}$ Nessler's reagent. Absorbance was measured at $450 \mathrm{~nm}$ using a visible spectrophotometer. One international unit of L-glutaminase $(\mathrm{U})$ was defined the amount of enzyme that liberates 1 $\mu \mathrm{mol}$ of ammonia from glutamate under optimum assay conditions. The enzyme yield was expressed as units $/ \mathrm{ml}$ according to Imada et al. [17].

\section{Protein estimation}

Protein was determined by the absorbance at $280 \mathrm{~nm}$ using bovine serum albumin (BSA) as the standard [21]. All the sets have been performed in triplicates.

\section{Effect of different natural wastes and leaching agents on L-glutaminase production}

The production of L-glutaminase by Aspergillus sp. ALAA-2000 under solid state fermentation was estimated in $250 \mathrm{ml}$ Erlenmeyer flasks containing $5 \mathrm{~g}$ of solid substrate; sugar cane bagasse, wheat bran, corn cobs, soy bean, kidney bean bran, wheat hay, rice bran, rice straw and corn casing separately moistened with mineral salt solution 10 $\mathrm{ml}$ of slates solution (glucose $0.6 \%, \mathrm{KH}_{2} \mathrm{PO}_{4} 0.1 \%, \mathrm{MgSO}_{4} .7 \mathrm{H}_{2} \mathrm{O} 0.05$ and $\mathrm{KCl} 0.05 \%$ ) the flasks were autoclaved, cooled, inoculated with spore suspension and incubated under static condition for 6 days fermentation period each fermented substrate was extracted with different leaching agent [22]. The leaching out of L-glutaminase from the fermented solids was carried out with different extractants such as hot water $\left(40^{\circ} \mathrm{C}\right)$, ethanol, acetone, Tween $80(1 \%)$, sodium chloride (0.1\%), citrate buffer $\mathrm{pH} 3$, phosphate buffer $\mathrm{pH} 7$, glycine buffer $\mathrm{pH} 12$, and at a ratio of $1: 5(\mathrm{w} / \mathrm{v})$.

\section{L-Glutaminase activity under submerged fermentation}

For the production of L-glutaminase by Aspergillus sp. ALAA2000, different fermentation media as a modified Czapek Dox medium, mineral salts and starch nitrate ware applied. Aspergillus sp. ALAA2000 strain was incubated in $250 \mathrm{ml}$ Erlenmeyer flasks containing $50 \mathrm{ml}$ of fermentation medium supplemented with L-glutamine and incubated at $27^{\circ} \mathrm{C}$ and $120 \mathrm{rpm}$ on a rotary shaker for 4 days. At the end of fermentation period the clear supernatant after centrifugation at $4000 \mathrm{rpm}$ for 20 min was used as enzyme preparations.

\section{Optimization of the culture condition for L-glutaminase production under submerged fermentation}

Various process parameters that enhance the yield of L-glutaminase by Aspergillus sp. ALAA-2000 strain in a modified Czapek Dox broth medium under shaking were investigated. The impact of incubation time (2-14 days), initial $\mathrm{pH}$ (3-9, adjusted with $1 \mathrm{M} \mathrm{HCl}$ or $\mathrm{NaOH}$ ), and incubation temperatures $\left(20-37^{\circ} \mathrm{C}\right)$ were evaluated. Moreover, the effect of incorporation of additional various carbon sources $(10 \mathrm{~g} / \mathrm{L})$ separately in modified Czapek Dox broth medium (raffinose, xylose, mannitol, mannose, sucrose, maltose, sorbose, lactose, galactose, fructose, starch, pectin, cellulose and dextrose) instead of its carbon source (glucose). Organic nitrogen sources; beef extract, yeast extract, peptone and urea as well as inorganic nitrogen sources; ammonium nitrate, ammonium sulfate, ammonium hydrogen citrate were examined for their ability separately to stimulate the enzyme production in modified Czapek Dox broth medium instead of L-glutamine as N-base. Ten amino acids (lysine, isoleucine, glycine, thiamine, arginine, treptophan, proline, glutamic acid, cysteine and methionine) were examined as a sole nitrogen source for L-glutaminase production. Each of them was added to the medium instead of its nitrogen source in such amount that the final concentration of $\mathrm{N}$-base remained unchanged. Different concentrations $(0.025 \%, 0.05 \%, 0.1 \%, 0.15 \%$ and $0.2 \%)$ of the most suitable amino acid source were tested for their ability to enhance the L-glutaminase production for Aspergillus sp. ALAA-2000 strain. Some element supplementations $\left(\mathrm{MgCl}_{2}, \mathrm{LiCl}, \mathrm{CaCl}_{2} \mathrm{~K}_{2} \mathrm{HPO}_{4}, \mathrm{BaCl}_{2}\right.$ and $\mathrm{NaCl}$ ) were supplementation to the modified Czapek Dox broth medium. Different concentrations $(0.025 \%, 0.05 \%, 0.1 \%, 0.15 \%$ and $0.2 \%$ ) of the most suitable element supplementation were tested for their ability to enhance the enzyme production by Aspergillus sp. ALAA-2000 strain. All the experiments were conducted in triplicate, subsequently and the mean values are considered.

\section{Purification and characterization of L-glutaminase}

The concentrated enzyme was subjected to ammonium sulphate fractionation with concentration ranging between $20 \%$ and $100 \%$ according to the method of Gomori [23]. The precipitate of crude enzyme was dissolved in a minimum volume of $0.2 \mathrm{M}$ phosphate buffer (pH 6.0) and dialyzed overnight in a dialysis bag against the same buffer at $4^{\circ} \mathrm{C}$. The L-glutaminase from ammonium sulphate precipitation (80\%) was loaded onto the DEAE-cellulose column chromatography which that equilibrated and eluted with $0.02 \mathrm{M}$ phosphate buffer $(\mathrm{pH}$ 8.0). The column was washed with four to five bed volumes of $0.02 \mathrm{M}$ phosphate buffer $(\mathrm{pH} 8.0)$. The bound protein was containing linear gradients of $\mathrm{NaCl}(0.1,0.25,0.5,1.0 \mathrm{M})$. The flow rate was $0.5 \mathrm{ml} / \mathrm{min}$. The fractions eluted at each $\mathrm{NaCl}$ concentration were collected, pooled and tested for protein and L-glutaminase activity [24]. The molecular weight of the purified L-glutaminase was estimated by sodium dodecyl sulfate-polyacrylamide gel electrophoresis (SDS-PAGE) as described by Laemmli [25].

The optimum reaction time for the partially purified enzyme was estimated at different times 10-100 min for L-glutaminase and then assayed by the direct nesslerization method. The optimum $\mathrm{pH}$ was determined by measuring enzymatic activity at $37^{\circ} \mathrm{C}$ using different buffers $(0.1 \mathrm{M})$ with various $\mathrm{pH}$ values as: citrate-phosphate buffer $(\mathrm{pH}$ $3,4,5$ and 6), phosphate buffer ( $\mathrm{pH}$ 6-7), Tris-HCl buffer ( $\mathrm{pH} \mathrm{8-9)}$ and glycine- $\mathrm{NaOH}$ buffer ( $\mathrm{pH}$ 10-12). Optimum temperature was assayed by measuring activity with varying temperatures $(27,37,47,57,67,77$ and $87^{\circ} \mathrm{C}$ ) at the optimum $\mathrm{pH}$ values.

Heat stability was determined by incubating the partially purified 
Citation: Ahmed MMA, Taha TM, Abo-Dahab NF, Hassan FSM (2016) Process Optimization of L-Glutaminase Production; a Tumour Inhibitor from Marine Endophytic Isolate Aspergillus sp. ALAA-2000. J Microb Biochem Technol 8: 382-389. doi: 10.4172/1948-5948.1000313

enzyme at various temperatures $\left(20-90^{\circ} \mathrm{C}\right)$ for $60 \mathrm{~min}$ and then the residual activity was determined at optimum $\mathrm{pH}$ and temperature. Partially purified L-glutaminase was incubated individually with different concentrations of $\mathrm{L}$-glutamine in the reaction mixture $(0.29$, $0.73,1.46,2.92,4.38$ and $5.85 \mathrm{mg} / \mathrm{ml}$ ) to find out the best substrate concentration for enzymatic assay under optimized assay conditions. Different concentrations $(0.05,0.125,0.25,0.5,0.75$ and $1.0 \mathrm{ml})$ of the partially purified L-glutaminase were incubated individually with the optimization concentration substrate solution in the reaction mixture to determine the best enzyme concentration under the optimized assay condition.

The effect of different metal ions including $\mathrm{Na}^{+}, \mathrm{Ca}^{2+}, \mathrm{Mn}^{2+}, \mathrm{Mg}^{2+}$, $\mathrm{Co}^{2+}, \mathrm{Ba}^{2+}$ and $\mathrm{Ni}^{2+}$ at a final concentration of $1.0 \mathrm{mM}$ as well as EDTA at different concentrations $(0.0001,0.0010 .005,0.01,0.05$ and $0.1 \mathrm{M})$ separately on purified L-glutaminase were studied. Residual activities in the presence of each chemical was assayed and compared with the control (without additions), which considered as $100 \%$ activity.

\section{Results and Discussion}

\section{Sccrening and production of L-glutaminase}

This study proved that Egyptian marine sponge Aplysina fistularis is a rich source of endophytic microorganisms. Whereas 18 fungal isolates were obtained on the isolation media peptone yeast extract glucose agar, potato dextrose agar and malt agar. All these marine endophytic isolates were evaluated as fruitful source of the therapeutic antitumor enzymes L-glutaminase. The activity of L-glutaminase enzyme was detected in all fungal strains. The fungal strain under the isolation number, ALAA-2000 was the most potent active producer. Therefore, this strain was identified and selected for furtherstudy. According to the analysis of ITS region sequence, together with its phenotypic and characteristics, the producing strain ALAA-2000 was identified as Aspergillus sp. and designated as Aspergillus sp. ALAA-2000 [20]. The screening and identification of filamentous fungi capable of secreting extracellular enzymes with biotechnological potential are activities of great importance [26]. Microbiology of sponges and corals can led to a huge number of other enzymes that applied in biotechnology such as cellulase, xylanase, keratinase, glucoamylase, pectinase, lipolytic activity, non-specific peroxidases, laccases, chitinase and glucanase [2732]. L-glutaminase activity varied in fungal strains obtained through different studies. In the study of Sajitha et al. [33] from 50 different endophytic fungi isolated from green and red seaweeds, 10 isolates produced L-glutaminase activity. Among 400 marine isolates screened from various marine niches, one isolate showed productivity of L-glutaminase [7] and among twenty one isolates of Aspergillus wentii (38\%) were capable of producing L-asparaginase and L-glutaminase [34]. The anticancer enzyme L-glutaminase are produced by a variety of fungi but the exclusive production of this enzyme in industry have been achieved mainly by Aspergillus species as A. fumigatus, Aspergillus sp. KUFS20, A. terreus MTCC 1782 [35-37].

\section{Production of L-glutaminase; antitumor enzyme under different fermentation processes}

When we used different natural sources as solid substrate fermentation such as sugar cane (bagasse), wheat bran, corn cobs, soy bean, kidney bean bran, wheat hay, rice bran, rice straw and corn casing, as are valuable and cheap energy sources of L-glutaminase productivity, with using different leaching agents such as hot water $40^{\circ} \mathrm{C}$, ethanol, acetone, sodium chloride ( $0.1 \%)$, phosphate buffer ( $\mathrm{pH} 7)$, glycine buffer ( $\mathrm{pH} 12)$, Tween 80 (1\%) and citrate buffer ( $\mathrm{pH} 3$ ) shown in Table 1. The hot water $40^{\circ} \mathrm{C}$ was the best leaching agent extracted of soy bean for L-glutaminase production $(21.89 \mathrm{U} / \mathrm{ml})$ followed by soy been extracted with phosphate buffer $(20.14 \mathrm{U} / \mathrm{ml})$, soy bean extracted with acetone $(19.69 \mathrm{U} / \mathrm{ml})$, wheat bran leached by $\mathrm{NaCl}(17.79 \mathrm{U} / \mathrm{ml})$, soy bean leached with $\mathrm{NaCl}(17.65 \mathrm{U} / \mathrm{ml})$, soy bean leached with citrate buffer $(17.00 \mathrm{U} / \mathrm{ml})$, soy been extracted with Tween $80(16.92 \mathrm{U} / \mathrm{ml})$, wheat bran extracted with citrate buffer $(16.00 \mathrm{U} / \mathrm{ml})$, and sugar can baggase extracted with $\mathrm{NaCl}(15.47 \mathrm{U} / \mathrm{ml})$, respectively. Consequently agro industrial residues proved to be promising sources for the industrial production of this therapeutic enzyme, especially soybean, wheat bran and sugar can baggase. Fermentation technology has been widely used for the production of a wide variety of substances of industrial, medical and agriculture. Fermentation technique must be economic and environmental advantages. Kiruthika and Saraswathy [38] supported soy bean as solid substrate in SSF for L-glutaminase production by Vibrioazureus JK-79 whereas Nathiya et al. [35] reported the maximum L-glutaminase form A. fumigatus was produced with paddy straw; El-Sayed [10] by using different agro-industrial byproducts as solid substrates for induction of L-glutaminase by $T$. koningii found that wheat bran was the best substrate $(12.1 \mathrm{U} / \mathrm{mg}$ protein). Furthermore, out of different agro industrial residues, A. flavus (FGNAS-7) produced the highest amount of L-glutaminase with ragi straw [39]. Moreover, Negi and Banerjee [40] tested various parameters such as leaching agent selection, amount of leaching agent, soaking time, and temperature in order to determine optimum extraction conditions of enzymes produced by A. awamari nakazawa MTCC 6652 and optimum conditions were achieved in a $10 \%$ glycerol. On the other hand, the effect of different three broth culture media named modified CzapekDox, mineral salts, and starch nitrate provided with $1 \%$ L-glutamine on L-glutaminase production by Aspergillus sp. ALAA-2000 were applied. Modified Dox medium showed the highest L-glutaminase activity $(91.92 \mathrm{U} / \mathrm{ml})$, while starch nitrate medium showed the lowest L-glutaminase activity $(73.24 \mathrm{U} / \mathrm{ml})$. The highest level of L-glutaminase activity observed after two days incubation period.

The whole fermentation broth and mycelium of Aspergillus sp. ALAA-2000 strain were subjected to different release and chemical

\begin{tabular}{|c|c|c|c|c|c|c|c|c|}
\hline \multirow[b]{2}{*}{ Substrate } & \multicolumn{8}{|c|}{ Leaching agent } \\
\hline & Hot water $40^{\circ} \mathrm{C}$ & Ethanol & Acetone & $\begin{array}{l}\mathrm{NaCl} \\
(0.1 \%)\end{array}$ & $\begin{array}{c}\text { Phosphate } \\
\text { buffer (pH 7) }\end{array}$ & $\begin{array}{l}\text { Glycine buffer } \\
\text { (pH 12) }\end{array}$ & $\begin{array}{c}\text { Tween } 80 \\
(1 \%)\end{array}$ & $\begin{array}{c}\text { Citrate buffer } \\
\text { (pH 3) }\end{array}$ \\
\hline Sugar cane & 0.73 & 3.65 & 0.44 & 15.47 & 1.46 & 1.60 & 4.09 & 0.29 \\
\hline Wheat bran & 11.09 & 3.94 & 9.78 & 17.79 & 6.57 & 8.75 & 14.88 & 16.00 \\
\hline Corn cobs & 1.60 & 1.75 & 4.67 & 7.29 & 0.29 & 6.57 & 2.63 & 11.67 \\
\hline Soy bean & 21.89 & 14.88 & 19.69 & 17.65 & 20.14 & 11.83 & 16.92 & 17.00 \\
\hline Kidney bean bran & 3.94 & 8.61 & 2.33 & 14.29 & 5.84 & 8.46 & 8.89 & 13.34 \\
\hline Wheat hay & 4.52 & 2.48 & 1.02 & 1.02 & 1.75 & 0.29 & 7.15 & 2.63 \\
\hline Corn casing & 5.84 & 9.78 & 0.73 & 0.15 & 0.29 & 7.44 & 5.83 & 3.93 \\
\hline Rice bran & 8.46 & 7.44 & 2.19 & 8.02 & 2.92 & 9.91 & 7.29 & 11.96 \\
\hline Rice straw & 4.96 & 3.94 & 1.60 & 0.58 & 2.63 & 0.29 & 5.39 & 3.06 \\
\hline
\end{tabular}

Table 1: Production of $L$-glutaminase $(\mathrm{U} / \mathrm{ml})$ under solid state fermentation (SSF) and extracted with different leaching agents. 
Citation: Ahmed MMA, Taha TM, Abo-Dahab NF, Hassan FSM (2016) Process Optimization of L-Glutaminase Production; a Tumour Inhibitor from Marine Endophytic Isolate Aspergillus sp. ALAA-2000. J Microb Biochem Technol 8: 382-389. doi: 10.4172/1948-5948.1000313

extraction treatments with different organic solvents. Table 2 illustrated that the chemical treatments were not fruitful for increasing the amount of extracted therapeutic enzyme, L-glutaminase from the mycelium of the strain. Leaching out of this anti-cancerous enzyme from the whole broth of Aspergillus sp. ALAA-2000 by toluene, ethyl acetate and butanol reduced glutaminase activity from 91.92 to 1.02 , 2.48 and $1.17 \mathrm{U} / \mathrm{ml}$, respectively after the 2 days of fermentation. Also reduction in yield was observed from 74.99 to $2.33,0.15$ and $13.28 \mathrm{U} /$ $\mathrm{ml}$, respectively after 4 days of fermentation. Moreover L-glutaminase was reduced from 81.70 to $3.06,0.44$ and $11.67 \mathrm{U} / \mathrm{ml}$, respectively after the $6^{\text {th }}$ day of fermentation. After 8 days of fermentation L-glutaminase yield was decreased from 83.31 to $1.46,9.19$ and $11.67 \mathrm{U} / \mathrm{m}$, respectively. At $10^{\text {th }}$ day of fermentation L-glutaminase yield decreased by 98.6 , 98.7 and $84.4 \%$, respectively. Whereas after 12 days of fermentation L-glutaminase were inhabited by $0.88,7.29$ and $0.73 \mathrm{U} / \mathrm{ml}$, respectively; 14 days incubation period resulted in reduction of L-glutaminase to $0.73,11.67$ and $0.44 \mathrm{U} / \mathrm{ml}$, respectively. These data clearly indicated that the L-glutaminase under study is extracellular enzymes. Extracellular enzymes are of potent important in industrial application in the terms of minimize the cost of production process.

The bioactive compounds are secreted into the fermentation broth. The substrates are utilized quite rapidly; hence need to be constantly replaced/supplemented with nutrients. An additional advantage of this technique is that purification of products is easier

\begin{tabular}{|c|c|c|c|c|}
\hline \multirow{2}{*}{ Incubation period (day) } & \multicolumn{4}{|c|}{ Treatment } \\
\cline { 2 - 5 } & Filtrate (control) & Toluene & Ethyl acetate & Butanol \\
\hline 2 & 91.92 & 1.02 & 2.48 & 1.17 \\
4 & 74.99 & 2.33 & 0.15 & 13.28 \\
6 & 81.70 & 3.06 & 0.44 & 11.67 \\
8 & 83.31 & 1.46 & 9.19 & 11.67 \\
10 & 84.62 & 1.31 & 1.02 & 13.13 \\
12 & 75.87 & 0.88 & 7.29 & 0.73 \\
14 & 71.49 & 0.73 & 11.67 & 0.44 \\
\hline
\end{tabular}

Table 2: Effect of different organic solvents on of L-glutaminase yield obtained from whole broth and mycelium of Aspergillus sp. ALAA-2000 after submerged fermentation for different incubation period.

\begin{tabular}{|c|c|c|c|}
\hline \multirow{2}{*}{$\mathbf{p H}$ value } & \multicolumn{3}{|c|}{ Enzyme production (U/mI) } \\
\cline { 2 - 4 } & $\mathbf{2 0 ^ { \circ } \mathbf { C }}$ & $\mathbf{2 7}^{\circ} \mathbf{C}$ & $\mathbf{3 7}^{\circ} \mathbf{C}$ \\
\hline 3 & 131.02 & 139.19 & 126.06 \\
4 & 115.26 & 219.14 & 122.56 \\
6 & 115.26 & 147.36 & 134.23 \\
7 & 129.85 & 157.57 & 142.98 \\
9 & 86.23 & 80.25 & 81.56 \\
\hline
\end{tabular}

Table 3: Effect of different $\mathrm{pH}$ and temperature values on L- glutaminase activity.
[41]. Elshafei et al. [42] and Siddalingeshwaraet al. [43] reported the production of L-glutaminase by $P$. brevicompactum NRC 829 and $A$. wentii KGSD4 mu under submerged fermentation, but Prasanna and Raju, [44] and Nathiya et al. [45] recorded solid state fermentation as the best fermentation technique for the production of L-glutaminase by $A$. oryzae NCIM1212 and A. flavus, respectively. The maximum L-glutaminase production by A. oryzae NCIM 1212 was recorded after 2 days of incubation period [44]. Conversely the highest L-glutaminase production by A. flavus (FGNAS-7) was obtained after 6 days [39].

\section{Process optimization of L-glutaminase production under submerged fermentation}

Effect of different $\mathrm{pH}$ and temperature values on L-glutaminase production from Aspergillus sp. ALAA-2000: To determine the optimum temperature and $\mathrm{pH}$, this supported the highest L-glutaminase production by Aspergillus sp. ALAA-2000. The results (Table 3) showed that $\mathrm{pH} 4$ at $27^{\circ} \mathrm{C}$ supported the highest L-glutaminase production $(219.14 \mathrm{U} / \mathrm{ml})$. L-Glutaminase was gradually decreased at higher $\mathrm{pH}$ to reach $80.25 \mathrm{U} / \mathrm{ml}$ at $\mathrm{pH} 9$ and $27^{\circ} \mathrm{C}$. Whereas incubation of Beauria sp. and A. fumigatus at $27^{\circ} \mathrm{C}$ and $30^{\circ} \mathrm{C}$ supported maximum L-glutaminase production [5,35], initial $\mathrm{pH}$ of 4 and 6 ensured L-glutaminase biosynthesis in Streptomyces variabilis ASU319 and A. fumigatus [35,46], respectively but Prasanna and Raju [44] reported that among a wide range of either incubation temperatures and initial $\mathrm{pH}$ the maximal yield of L-glutaminase production by A. oryzae NCIM1212 was attained at $30^{\circ} \mathrm{C}$ and $\mathrm{pH} 7$.

Effect of different concentrations of L-glutamine on L-glutaminase production: L-glutamine is the inducer for L-glutaminase production. Different inducer concentrations $(0.5,1,1.5,2$ and $2.5 \%)$ were added to the modified Dox medium individually to determine the optimum concentration for the enzyme production (Table 4). L-glutamine at concentration of $2.5 \%$ supported the highest induction of L-glutaminase up $78.79 \mathrm{U} / \mathrm{ml}$. The high yield of L-glutaminase $(32.7 \mathrm{U} / \mathrm{ml})$ produced by Streptomyces griseus when used L-glutamine as substrate due to L-glutamine is the specific inducers for L-glutaminase [47].

Effect of different nitrogen and carbon sources on L-glutaminase production: The effect of different organic nitrogen sources such as peptone, beef extract, yeast extract, urea, and glutamine as well as inorganic sources such as ammonium sulphate, diammonium citrate, sodium nitrate, and ammonium nitrate were tested. Each one of these nitrogen sources was added to the modified Dox medium individually at concentration in comparison to the enzymatic inducer L-glutamine was evaluated. Results (Table 4) indicated that the endophytic

\begin{tabular}{|c|c|c|c|c|c|c|c|c|c|}
\hline $\begin{array}{l}\text { L-Glutamine } \\
(\%)\end{array}$ & $\begin{array}{c}\text { L-Glutaminase } \\
(\mathrm{U} / \mathrm{ml})\end{array}$ & Nitrogen sources & $\begin{array}{c}\text { L-Glutaminase } \\
(\mathrm{U} / \mathrm{ml})\end{array}$ & Carbon source & $\begin{array}{l}\text { L-Glutaminase } \\
(\mathrm{U} / \mathrm{ml})\end{array}$ & $\begin{array}{c}\text { Supplementation } \\
\text { elements }\end{array}$ & $\begin{array}{c}\text { L- } \\
\text { Glutaminase } \\
(\mathrm{U} / \mathrm{ml})\end{array}$ & Amino acids & $\begin{array}{c}\text { L- } \\
\text { Glutaminase } \\
(\mathrm{U} / \mathrm{ml})\end{array}$ \\
\hline $\begin{array}{l}0.5 \\
1.0 \\
1.6 \\
2.0 \\
2.5\end{array}$ & $\begin{array}{l}32.09 \\
52.52 \\
73.83 \\
75.87 \\
78.79\end{array}$ & $\begin{array}{c}\text { Without nitrogen } \\
\text { Peptone } \\
\text { Beef extract } \\
\text { Yeast extract } \\
\text { Urea } \\
\text { Ammonium sulphate } \\
\text { Diammonium citrate } \\
\text { Sodium nitrate } \\
\text { Ammonium nitrate } \\
\text { L-Glutamine }\end{array}$ & $\begin{array}{c}4.52 \\
69.30 \\
31.66 \\
59.09 \\
41.29 \\
77.32 \\
93.67 \\
7.59 \\
91.92 \\
109.43\end{array}$ & $\begin{array}{l}\text { Without carbon } \\
\text { Raffinose } \\
\text { Xylose } \\
\text { Mannitol } \\
\text { Mannose } \\
\text { Sucrose } \\
\text { Maltose } \\
\text { Sorbose } \\
\text { Lactose } \\
\text { Galactose } \\
\text { Fructose } \\
\text { Starch } \\
\text { Pectin } \\
\text { Cellulose } \\
\text { Dextrose }\end{array}$ & $\begin{array}{c}119.64 \\
84.62 \\
100.67 \\
104.90 \\
121.09 \\
119.20 \\
99.07 \\
115.26 \\
103.44 \\
109.72 \\
100.67 \\
107.97 \\
113.80 \\
107.97 \\
124.02\end{array}$ & $\begin{array}{c}\text { Control } \\
\mathrm{MgCl}_{2} \\
\mathrm{LiCl}^{2} \\
\mathrm{CaCl}_{2} \\
\mathrm{~K}_{2} \mathrm{HPO}_{4} \\
\mathrm{BaCl}_{2} \\
\mathrm{NaCl}^{2}\end{array}$ & $\begin{array}{l}86.08 \\
97.75 \\
74.41 \\
71.49 \\
57.92 \\
77.62 \\
78.79\end{array}$ & $\begin{array}{l}\text { Control } \\
\text { Lysine } \\
\text { Isoleucine } \\
\text { Glycine } \\
\text { Thiamine } \\
\text { Arginine } \\
\text { Treptophane } \\
\text { Proline } \\
\text { Glutamic acid } \\
\text { Cystine } \\
\text { Methonine }\end{array}$ & $\begin{array}{l}86.08 \\
134.67 \\
124.16 \\
126.93 \\
126.20 \\
127.37 \\
119.64 \\
132.12 \\
117.01 \\
135.98 \\
125.91\end{array}$ \\
\hline
\end{tabular}

Table 4: Effect of different concentrations of substrate, nitrogen and carbon sources, supplementation elements as well as amino acids on L-glutaminase production. 
Citation: Ahmed MMA, Taha TM, Abo-Dahab NF, Hassan FSM (2016) Process Optimization of L-Glutaminase Production; a Tumour Inhibitor from Marine Endophytic Isolate Aspergillus sp. ALAA-2000. J Microb Biochem Technol 8: 382-389. doi: 10.4172/1948-5948.1000313

Aspergillus sp. ALAA-2000 strain was required the inducer L-glutamine for the best biosyntheses of L-glutaminase $(109.43 \mathrm{U} / \mathrm{ml})$. However beef extract and sodium nitrate showed lowest production of L-glutaminase (31.66 and $7.59 \mathrm{U} / \mathrm{ml}$, respectively) by Aspergillus sp. ALAA-2000. Katikala et al. [48] reported that marine bacterial isolate LG24 gave the highest yield of extracellular L-glutaminase $22.68 \mathrm{U} / \mathrm{ml}$ in $120 \mathrm{~h}$ when L-glutamine supplemented as sole carbon and nitrogen source in the media.

On the other hand, to determine the best carbon sources for therapeutic enzyme production L-glutaminase produced by Aspergillus sp. ALAA-2000 grown in modified Dox medium supplemented with different carbon sources are represented in Table 4. It was obvious that dextrose increased the L-glutaminase production by Aspergillus sp. ALAA-2000 to $124.02 \mathrm{U} / \mathrm{ml}$ followed by mannose, sucrose, sorbose, pectin, galactose, cellulose, starch, mannitol, lactose, xylose, maltose and raffinose $(121.09,119.20,115.26,113.80,109.72,107.97,107.97$, 104.90, 103.44, 100.67, 99.07 and $84.62 \mathrm{U} / \mathrm{ml}$ ), respectively. Overall, all carbon sources did not exhibited much significant increase in L-glutaminase production due to Dox modify medium free carbon relatively yielded a high amount of L-glutaminase $(119.64 \mathrm{U} / \mathrm{ml})$. On the contrary, the yield of L-glutaminase from S. griseus was increased to $26.3 \mathrm{U} / \mathrm{ml}$ by utilized the galactose as the carbon source [47].

Effect of different amino acids on L-glutaminase production: Data illustrated in Table 4 showed effect lysine, isoleucine, glycine, thiamine, arginine, treptophan, proline, glutamic acid, cysteine, andmethionine on L-glutaminase production. All amino acids had stimulation effect on L-glutaminase production with different ratio ranged between $57.8 \%$ with cysteine to $36 \%$ with glutamic acid and then the impact of different concentrations of cysteine, the best amino acids for L-glutaminase production by the marine endophytic strain Aspergillus sp. ALAA-2000 was studied. Out of this concentration cysteine at a concentration of $0.1 \%$ supported the highest L-glutaminase production $135.98 \mathrm{U} / \mathrm{ml}$. Amino acids were served as source of energy and carbon in addition to nitrogen as previously reported for L-glutaminase production by Fusarium sp. [46].

Effect of addition and elimination of different supplementation elements on L-glutaminase production: Magnesium chloride enhanced L-glutaminase production by Aspergillus sp. ALAA-2000 to $97.75 \%$ but $\mathrm{LiCl}, \mathrm{CaCl}_{2}, \mathrm{~K}_{2} \mathrm{HPO}_{4}, \mathrm{BaCl}_{2}$ and $\mathrm{NaCl}$ decrease it to 74.41 , $71.49,57.92,77.62$ and $78.79 \mathrm{U} / \mathrm{ml}$, respectively (Table 4). Therefore, the effect different concentrations of $\mathrm{MgCl}_{2}$ on L-glutaminase production were studied. L-glutaminase activity increased with the increasing of $\mathrm{MgCl}_{2}$ concentration till $0.1 \%$ after that decreased. The main components of the modified Dox medium are $\mathrm{KCl}$, $\mathrm{MgSO}_{4} .7 \mathrm{H}_{2} \mathrm{O}$, and $\mathrm{KH}_{2} \mathrm{PO}_{4}$. Elimination of these components from culture medium did not strongly inhibited L-glutaminase production. Inhibition ratio reached up to $6 \%, 3 \%$ and $22 \%$ with the elimination of $\mathrm{KCl}, \mathrm{MgSO}_{4} .7 \mathrm{H}_{2} \mathrm{O}$, and $\mathrm{KH}_{2} \mathrm{PO}_{4}$, respectively. $\mathrm{Na}^{+}$enhanced of L-glutaminase production by A. fumigatus and A. oryzae NCIM 1212 $[35,44]$.

\section{Partially purification of L-glutaminase with DEAE-cellulose}

The purification steps from the crude extract of Aspergillus sp. ALAA-2000 are summarized in Table 5 and Figure 1. L-Glutaminase was purified from the culture filtrate by $80 \%$ saturation of ammonium sulfate (the fraction showed the highest glutaminase activity), resulted in specific activity of $9.52 \mathrm{U} / \mathrm{mg}$ protein, 8.89 purification folds followed by DEAE-cellulose column chromatography. The purification of the glutaminase was increased 36.72 fold with overall yields of $37.42 \%$. The partially purified of L-glutaminase produced by $P$. brevicompactum NRC 829 has total activity $321.6 \mathrm{U}$, total protein $0.37 \mathrm{mg}$, Specific activity $869.08(\mathrm{U} / \mathrm{mg})$, purification 162.75 -fold and yield $48.21 \%$ after Sephadex G-200 [42]. While Ali and Mohamed [49] reported that the total activity $44 \mathrm{U}$, total protein $0.33 \mathrm{mg}$, specific activity $133 \mathrm{U} / \mathrm{mg}$, purification 230 -fold and yield $25 \%$ of L-glutaminase produced by $P$. politans NRC510.

\begin{tabular}{|c|c|c|c|c|c|}
\hline Purification Step & Total activity $\mathbf{( U )}$ & Total protein $\mathbf{( m g})$ & Specific activity $\mathbf{( U / m g )}$ & Yield (\%) & Fold \\
\hline Filtrate & 210 & 195 & 1.07 & 100 & 1 \\
$\left(\mathbf{N H}_{4}\right)_{\mathbf{2}} \mathbf{S O}_{4}$ precipitation & 120 & 12.6 & 9.52 & 57.14 & 8.89 \\
$\mathrm{DEAE}$-cellulose & 78.6 & 2.0 & 39.3 & 37.42 & 36.72 \\
\hline
\end{tabular}

Table 5: Summary of the purification steps of L-glutaminase.

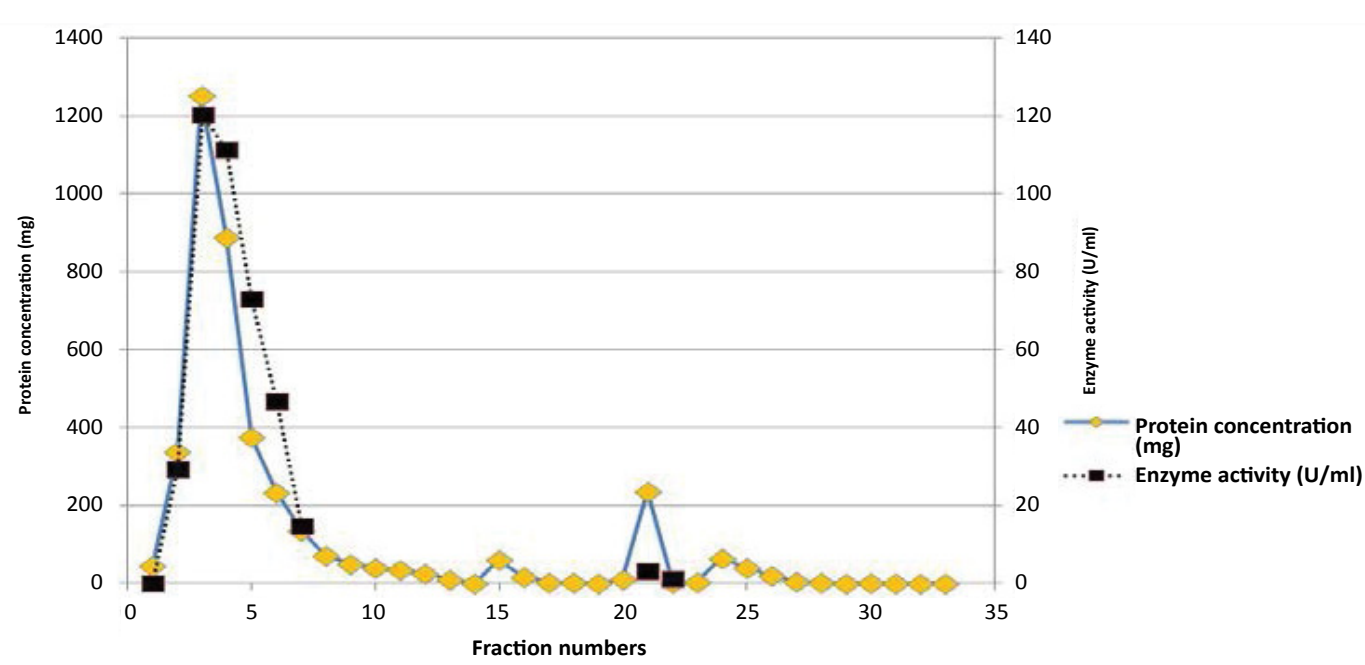

Figure 1: Elution diagram of L-glutaminase using DEAE-cellulose column chromatography. 
Citation: Ahmed MMA, Taha TM, Abo-Dahab NF, Hassan FSM (2016) Process Optimization of L-Glutaminase Production; a Tumour Inhibitor from Marine Endophytic Isolate Aspergillus sp. ALAA-2000. J Microb Biochem Technol 8: 382-389. doi: 10.4172/1948-5948.1000313

\section{Characterization of partially purified L-glutaminase activity}

Due to the purification of L-glutaminase showed the maximum single peak of L-glutaminase relative activity $(107.2 \%)$ produced by Aspergillus sp. ALAA- 2000 at $47^{\circ} \mathrm{C}$ refer to the mono meric nature of L-glutaminase enzymes. The thermo stability of L-glutaminase activities showed a wide range of L-glutaminase thermo stability from $\left(30^{\circ} \mathrm{C}\right.$ to $\left.60^{\circ} \mathrm{C}\right)$ and higher than this temperature stability gradually decreased. Maximum thermo stability of L-glutaminase activity at $40^{\circ} \mathrm{C}$ and $50^{\circ} \mathrm{C}(100$ and $100 \%)$, respectively and sharply decreases the activity $(41 \%)$ at $90^{\circ} \mathrm{C}$ (Table 6). The maximum activity of purified L-glutaminase from $P$. brevicompactum NRC 829 and S. variabilis were insured at incubation temperatures $30^{\circ} \mathrm{C}$ and $50^{\circ} \mathrm{C}$, respectively $[42,46]$. Furthermore, Elshafei et al. [42] reported that L-glutaminase was stable at $50^{\circ} \mathrm{C}$ to $60^{\circ} \mathrm{C}$ for $60 \mathrm{~min}$ and it retained about $92 \%$ and $66 \%$ of its initial activity after incubation at $70^{\circ} \mathrm{C}$ for $30 \mathrm{~min}$ and $80^{\circ} \mathrm{C}$ for $5 \mathrm{~min}$, respectively without the substrate.

The L-glutaminase produced by marine endophytic Aspergillus sp. ALAA-2000 strain exhibited classical pattern of $\mathrm{pH}$ activity relationship with pH optimum at pH10 (Table 6). Elshafei et al. [42] and Dura et al. [24] reported that the $\mathrm{pH} 7$ and 8.5 were increased L-glutaminase activity purified from P. brevicompactum NRC 829 and Debaryomyces sp. CECT 11815, respectively. Figure 2 showed that, the activity of partially purified L-glutaminase was tested at 10, 20, 30, 40, 50, 60, 70, 80, 90 and $100 \mathrm{~min}$ incubation times. The results showed on peak of activity after $30 \mathrm{~min}$ of incubation and it was $100 \%$. The best incubation

\begin{tabular}{|c|c|c|c|}
\hline $\begin{array}{c}\text { Thermo } \\
\text { stability }\end{array}$ & $\begin{array}{c}\text { L-Glutaminase relative } \\
\text { activity (\%) }\end{array}$ & $\mathbf{p H}$ & $\begin{array}{c}\text { L-Glutaminaserelative } \\
\text { activity } \\
(\%)\end{array}$ \\
\hline & & 3 & 62.2 \\
20 & 81.0 & 4 & 92.8 \\
30 & 96.0 & 5 & 92.9 \\
40 & 100.0 & 6 & 95.8 \\
50 & 100.0 & 7 & 96.7 \\
60 & 92.0 & 8 & 100 \\
70 & 88.0 & 9 & 123.3 \\
80 & 62.0 & 10 & 133.0 \\
90 & 41.0 & 11 & 120.8 \\
& & 12 & 104.0 \\
\hline
\end{tabular}

Table 6: Effect of thermo stability and different $\mathrm{pH}$ values on L-glutaminase activity. time for L-glutaminase production by P. brevicompactum NRC 829 and S.variabilis was $60 \mathrm{~min}[42,46]$.

The effect of different concentrations of L-glutamine $0.29,0.73$, $1.46,2.92,4.38$ and $5.85 \mathrm{mg} / \mathrm{ml}$ on the activity of L-glutaminase were detected. The activity of L-glutaminase was increased with increasing substrate concentration ratio to $4.38 \mathrm{mg} / \mathrm{ml}$ of L-glutamine $(114.1 \mathrm{U} / \mathrm{ml})$. Increasing substrate concentration resulted decreasing in the activity of L-glutaminase. Different partially purified enzymes concentrations, $0.05,0.125,0.25,0.5,0.75$ and $1 \mathrm{ml}$ of L-glutaminase were attempted in the enzymatic reaction with glutamine at concentration of $0.75 \mathrm{mg} /$ $\mathrm{ml}$. The suitable enzyme concentration in the reaction mixture that supported the highest activity was $113.4 \%$ for L-glutaminase produced by $1 \mathrm{ml}$. Elshafei et al. [42] and Ali and Mohamed [49] reported the high affinity of L-glutaminase activity produced by $P$. brevicompactum NRC 829 and P. politans NRC510 with $1.66 \mathrm{mM}$ and $10 \mu \mathrm{mol}$ concentrations of L-glutamine, respectively.

The effect of $\mathrm{Ni}^{2+}, \mathrm{Ba}^{2+}, \mathrm{Ca}^{2+}, \mathrm{Na}^{+}, \mathrm{Co}^{2+}, \mathrm{Mn}^{2+}$ and $\mathrm{Mg}^{2+}$ with final concentration of $0.5 \mathrm{mM}$ of each cation on partially purified L-glutaminase activities was studied. Compared to control $\mathrm{Ba}^{2+}, \mathrm{Ca}^{2+}$, $\mathrm{Na}^{+}, \mathrm{Co}^{2+}, \mathrm{Mn}^{2+}$ and $\mathrm{Mg}^{2+}$ increase the L-glutaminase activity by 15.7 , $6.8,41.7,15.4,9.4$ and 15.8 , respectively but $\mathrm{Ni}^{2+}$ achieved decrease enzyme activity. The maximum activator cation is $\mathrm{Na}^{+}$by $41.7 \%$ compared with control. On the other hand, the effect of different EDTA concentrations $(0.0001,0.001,0.005,0.01,0.05$ and $0.1 \mathrm{M})$ on the activity of partially purified L-glutaminase was studied. Results indicated that different EDTA concentrations have no effect on L-glutaminase activity which means that L-glutaminase enzymes was represent as a non metallicenzyme. Ali and Mohamed [49] and Elshafei et al. [42] reported that sodium chloride was the best activator for L-glutaminase activity from $P$. politans NRC 510 and P. brevicompactum NRC 829. Also, Elshafei et al. [42] reported L-glutaminase produced by $P$. brevicompactum NRC 829 as non metalloenzyme but Abd-Alla et al. [46] reported L-glutaminase produced by S.variabilis as metallo enzyme.

\section{Conclusion}

The potential of isolated marine endophytic strain Aspergillus sp. ALAA-2000 for L-glutaminase production was analyzed under different fermentation modes with different process parameters. Maximum production was supported with L-glutamine, dextrose,

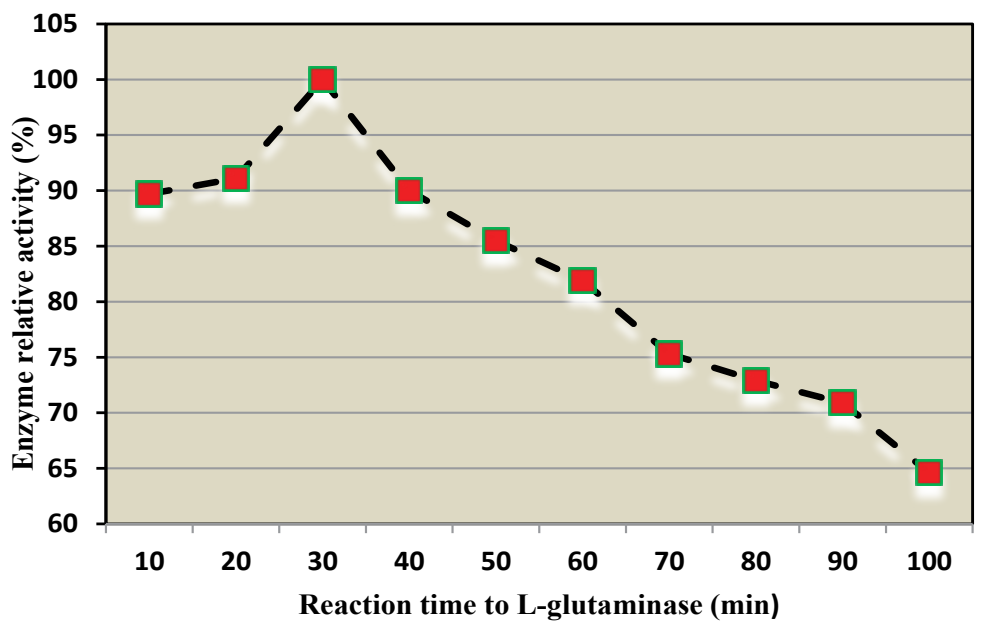

Figure 2: Effect of reaction time on L-glutaminase activity. 
Citation: Ahmed MMA, Taha TM, Abo-Dahab NF, Hassan FSM (2016) Process Optimization of L-Glutaminase Production; a Tumour Inhibitor from Marine Endophytic Isolate Aspergillus sp. ALAA-2000. J Microb Biochem Technol 8: 382-389. doi: 10.4172/1948-5948.1000313

cysteine, and Magnesium chloride under $\mathrm{SmF}$ at $\mathrm{pH} 4$ and $27^{\circ} \mathrm{C}$. The parameters of purified L-glutaminase were optimized as follow: $\mathrm{pH} 10$, stable at $40^{\circ} \mathrm{C}$ to $50^{\circ} \mathrm{C}$, reaction time $30 \mathrm{~min}$, and L-glutamine $4.38 \mathrm{mg} /$ $\mathrm{ml}$, whereas the maximum activator cation is $\mathrm{Na}^{+}$and different EDTA concentrations have no effect on L-glutaminase activity.

\section{References}

1. Pal S, Maity P (1992) Antineoplastic activities of purified bacterial glutaminase on transplanted tumor systems. Indian J Cancer Chemother 13: 73-76.

2. Roberts J, Holcenberg JS, Dolowy WC (1970) Antineoplastic activity of highly purified bacterial glutaminases. Nature 227: 1136-1137.

3. Yokotsuka T (1985) Fermented protein foods in the Orient, with emphasis on shoy and miso in Japan. Applied Science 197-247.

4. Roberts J, McGregor WG (1991) Inhibition of mouse retroviral disease by bioactive glutaminase-asparaginase. J Gen Virol 72 : 299-305.

5. Sabu A, Keerthi TR, Kumar RS, Chandrase K (2000) L-Glutaminase production by marine Beaueria sp. under solid state fermentation. Process Biochemistry 35: 705-710.

6. Kashyap P, Sabu A, Pandey A, Szakacs G, Soccol CR (2002) Extracellular L-glutaminase production by Zygosaccharomyces rouxiiunder solid-state fermentation. Proc Biochem 38: 307-312.

7. lyer PV, Singhal RS (2009) Screening and selection of marine isolate for L-glutaminase production and media optimization using response surface methodology. Appl Biochem Biotechnol 159: 233-250.

8. Weng CJ, Chau CF, Yen GC, Liao JW, Chen DH, et al. (2009) Inhibitory effects of Ganoderma lucidum on tumorigenesis and metastasis of human hepatoma cells in cells and animal models. J Agric Food Chem 57: 5049-5057.

9. Balagurunathan R, Radhakrishnan M, Somasundaram S (2010) L-Glutaminase producing actinomycetes from marine sediments selective isolation, sem quantitative assay and characterization of potential strain. Aust J Basic App Sci 4: 698-705

10. El-Sayed AS (2009) L-glutaminase production by Trichoderma koningii under solid-state fermentation. Indian J Microbiol 49: 243-250.

11. Masuo N, Ito K, Yoshimune K, Hoshino M, Matsushima K, et al. (2004) Molecular cloning, overexpression and purification of Micrococcus luteus K-3type glutaminase from Aspergillus oryzae RIB40. Protein Expr Purif 38: 272 278.

12. Pallem C, Manipati S, Somalanka SR (2010) Process optimization of L-glutaminase production by Trichoderma koningii under solid state fermentation (SSF). Int J Appl Biol Pharm Technol 1: 1168-1174.

13. Tomita K, Yano T, Kumagai H, Tochikura $\mathrm{T}$ (1988) Formation of glutamyl glycine by extracellular glutaminase of Aspergillus oryzae. J Ferment Technol 66: 299-304.

14. Amina N, Muhammad MH, Muhammad A, Tassawar H (2009) Association of response to combined interferon Alpha- $2 b$ and ribvirin therapy in patients of chronic hepatitis $C$ with serum alanine aminotrase levels and severity of the disease on liver biopsy. J Ayub Med Coll Abbottabad 21: 103-106.

15. Liu K, Ding X, Deng B, Chen W (2009) Isolation and characterization of endophytic taxol-producing fungi from Taxus chinensis. J Ind Microbio Biotechnol 36: 1171-1177.

16. Sithranga Boopathy N, Kathiresan K (2010) Anticancer drugs from marine flora: An overview. J Oncol 2010: 214186

17. Imada A, Igarasi S, Nakahama K, Isono M (1973) Asparaginase and glutaminase activities of micro-organisms. J Gen Microbiol 76: 85-99.

18. Yamamoto S, Hirooka H (1974) Production of glutaminase by Aspergillus sojae. J Ferment Technol 52: 564-569.

19. Pandey A, Selvakumar P, Soccol CR, Nigam $P$ (1999) Solid state fermentation for the production of industrial enzymes. Curr Sci 77: 149-162.

20. Ahmed MA, Nageh ADF, Taher TM, Fareed HSM (2015) Production, purification and characterization of L-asparaginase from marine endophytic Aspergillus sp. ALAA-2000 under submerged and solid state fermentation. J Microb Biochem Technol 7: 165-172.

21. Suntornsuk KW, Hang YD (1997) Purification and characterization of glucoamylase from Rhizopus oryzae mutant. J Sci Soc Thailand 9: 199-208.
22. Yasser R, Abdel-Fattah, Zakia A (2002) L-Asparaginase production by Pseudomonas aeruginosa in solid-state culture: Evaluation and optimization of culture conditions using factorial designs. Prospects in Biochem 38: 115-122.

23. Gomori G (1955) Preparation of buffers for use in enzyme active studies. In: Methods in Enzymology.

24. Durá MA, Flores M, Toldrá $F$ (2002) Purification and characterisation of a glutaminase from Debaryomyces spp. Int J Food Microbiol 76: 117-126.

25. Laemmli UK (1970) Cleavage of structural proteins during the assembly of the head of bacteriophage T4. Nature 227: 680-685

26. Zambare V (2010) Solid state fermentation of Aspergillus oryzae for glucoamylase production on agro residues. Int J Life Sci 4: 16-25

27. El-Bondkly AMA, El-Gendy Mervat MA (2011) Cellulase production from agricultural residues by recombinant fusant strain of a fungal endophyte of the marine sponge Latrunculia corticata for production of ethanol. Antonie van Leeuwenhoek 101: 331-346.

28. El-Gend MMA, El-Bondkly AMA (2014) Optimization of solid state fermentation and leaching process parameters for improvement xylanase production by endophytic Streptomyces sp. ESRAA-301097. Journal of Microbial and Biochemical Technology 6: 154-166

29. El-Gendy MM (2010) Keratinase production by endophytic Penicillium spp. Morsy1 under solid-state fermentation using rice straw. Appl Biochem Biotechnol 162: 780-794.

30. El-Gendy MA (2012) Production of glucoamylase by marine endophytic Aspergillus sp. JAN-25 under optimized solid-state fermentation conditions on agro residues. Australian Journal of Basic and Applied Sciences 6: 41-54.

31. Li HM, Sullivan R, Moy M, Kobayashi DY, Belanger FC (2004) Expression of a novel chitinase by the fungal endophyte in Poa ampla. Mycologia 96: 526-536.

32. Promputtha I, Lumyong S, Dhanasekaran V, McKenzie EH, Hyde KD, et al (2007) A phylogenetic evaluation of whether endophytes become saprotrophs at host senescence. Microb Ecol 53: 579-590.

33. Sajitha N, Vasuki S, Suja M, Kokilam G, Gopinath M (2013) Screening of L-glutaminase from seaweed endophytic fungi. Int Res J Pharm Appl Sci 3: 206-209.

34. Usha R, Mala KK, Venil CK, Palaniswamy M (2011) Screening of Actinomycetes from mangrove ecosystem for L-asparaginase activity and optimization by response surface methodology. Pol J Microbiol 60: 213-221.

35. Nathiya K, Sooraj S, Nath J, Angayar K, Palaniswamy M (2010) Paddy straw: An inexpensive substrate for the production of L-glutaminase using native strain Aspergillus fumigates. International J Pharma BioSciences 2: 1107-1115.

36. Rani ASA, Lalitha S, Praveesh B (2012) Isolation and screening of $\mathrm{L}$-asparaginase producing fungi from soil samples. International J Pharmacy and Pharmaceutical Sciences 4: 279-282.

37. Varalakshmi V, Raju KJ (2009) Optimization of L-asparaginase production by Aspergillus terrus MTCC 1782 using bajra seed flour under solid state fermentation. Inter J Res Eng Technol 2: 2321-2332.

38. Kiruthika J, Saraswathy N (2013) Production of L-glutaminase and its optimization from a novel marine isolate Vibrio azureus JK-79. African Journal of Biotechnology 12: 1107- 1115.

39. Rashmi AM, Gopinath SM, Krishan K, Narasimha MTP (2012) A new solid state fermentation for the production of L-glutaminase by Aspergillus flavus (FGNAS-7). International J of Latest Research in Science and Technology 1 : 304-307.

40. Negi S, Banerjee R (2010) Optimization of culture parameters to enhance production of amylase and protease from Aspergillus awamori in a single fermentation. African J Biochemistry Research 4: 73-80.

41. Subramaniyam R, Vimala R (2012) Solid state and submerged fermentation for the production of bioactive substance: A comparative I J S N 3: 480-486.

42. Elshafei AM, Mohamed MH, Mohamed AA, Dalia MA, Dina HE (2012) Purification, characterization and antitumor activity of L-asparaginase from Penicillium brevicompactum NRC 829. British Microbiology Research Journal 2: 158-174.

43. Siddalingeshware KG, Dhatri DN, Pramada T, Vishwanata T, Sudipta KM, et al. (2010) Rapid screening and confirmation of L-glutaminase producing nove Aspergillus wentii. Inter J Chem Tech Research 2: 830-833. 
Citation: Ahmed MMA, Taha TM, Abo-Dahab NF, Hassan FSM (2016) Process Optimization of L-Glutaminase Production; a Tumour Inhibitor from Marine Endophytic Isolate Aspergillus sp. ALAA-2000. J Microb Biochem Technol 8: 382-389. doi: 10.4172/1948-5948.1000313

44. Prasanna KL, Raju KJ (2011) Production of L-glutaminase by Aspergillus oryzae NCIM 1212 under solid state fermentation using agro-residues. An International Peer Review E-3 J of Sciences 2: 261-269.

45. Nathiya K, Sooraj S, Nath J, Angayar K, Palaniswamy M (2011) Optimised production of L-glutaminase: A tumour inhibitor from Aspergillus flavus cultured on agroindustrial residues. African Journal of Biotechnology 10: 13887-13894.

46. Abd-Alla MH, El-Sayed A, Rasmey AM (2013) Biosynthesis of L-glutaminase by Streptomyces variabilis ASU319 isolated from rhizosphere of Triticum vulgaris. Universal Journal of Microbiology Research 1: 27-35.
47. Kumar SS, Muthuvelayudham R, Viruthagiri T (2013) Medium optimization for production of L-glutaminase (EC 3.5.1.2) by Streptomyces griseus under submerged fermentation. Inter J Sci Eng Application 2: 1-5.

48. Katikala PK, Bobbarala V, Tadimalla P, Guntuku GS (2009) Screening of L-glutaminase producing marine bacterial cultures for extracellular production of L-glutaminase. Int J Chemtech Res 1: 1232-1235.

49. Ali THNHA, Mohamed LA (2009) Glutaminase amidohydrolase from Penicillium politans NRC 510 Pol. J Food Nutr Sci 59: 211-217. 